\title{
ON THE AGES OF SOME GRANITOID AND SCHIST COMPLEXES IN NORTHERN FINLAND
}

\author{
RAIMO LAUERMA
}

\begin{abstract}
LAUERMA, RAIMO 1982: On the ages of some granitoid and schist complexes in northern Finland. Bull. Geol. Soc. Finland 54, 1-2, $85-100$.
\end{abstract}

Contact observations and most radiometric datings indicate that the large complex of granitoid rocks and migmatites in Central Lapland is late Svecokarelian (Proterozoic) in age. The geological setting of the complex suggests, however, that it previously formed the basement for the Proterozoic sedimentation and a source of some of the sedimentary material. About $1800 \mathrm{Ma}$ ago it apparently underwent partial anatexis, especially near the Proterozoic schist belts.

The concept that some parts of the schist areas of Kuusamo, Salla and Central Lapland are of Archean age is disputable. The Salla schist area, which some authors maintain is an Archean greenstone belt, is obviously Proterozoic in age. U-Pb ages reported for zircons, titanites and monazites from granitoid rocks from six localities in Kuusamo, Salla, Kemijärvi and Rovaniemi areas range from 2738 $\mathrm{Ma}$ to $1770 \mathrm{Ma}$.

Raimo Lauerma, Geological Survey of Finland, SF-02150 Espoo 15, Finland.

\section{Introduction}

The present-day concept of the major features of the Precambrian bedrock in Finland is based mainly on the general geological mapping at a scale of $1: 400000$ started in the 1890 s and completed in 1980 . The reasons for a map of this type and the underlying principles and goals are summarized by Sederholm (1903). Investigations were usually started in areas where the effects of the geological phenomena were more readily explicable. The results from these investigations were then applied to more complicated areas. Large, geologically monotonous areas composed mainly of granitoid rocks and migmatites were subjected to reconnaissance only, whereas localities of great geological importance, especially with regard to the age relations of the rocks, were investigated in detail and often mapped on a large scale in the field.

According to Sederholm's original plans (op.cit.), about $10000 \mathrm{~km}^{2}$ should be mapped every year in southern Finland and at least $5000 \mathrm{~km}^{2}$ in northern Finland. The areas of the map sheets B 6 Ylitornio, C 6 Rovaniemi (Hackman 1910 a, b) and D 6 Kuolajärvi (Hackman \& Wilkman 1925) totalling some $40000 \mathrm{~km}^{2}$, were investigated at a rate approaching that recommended by Sederholm. 


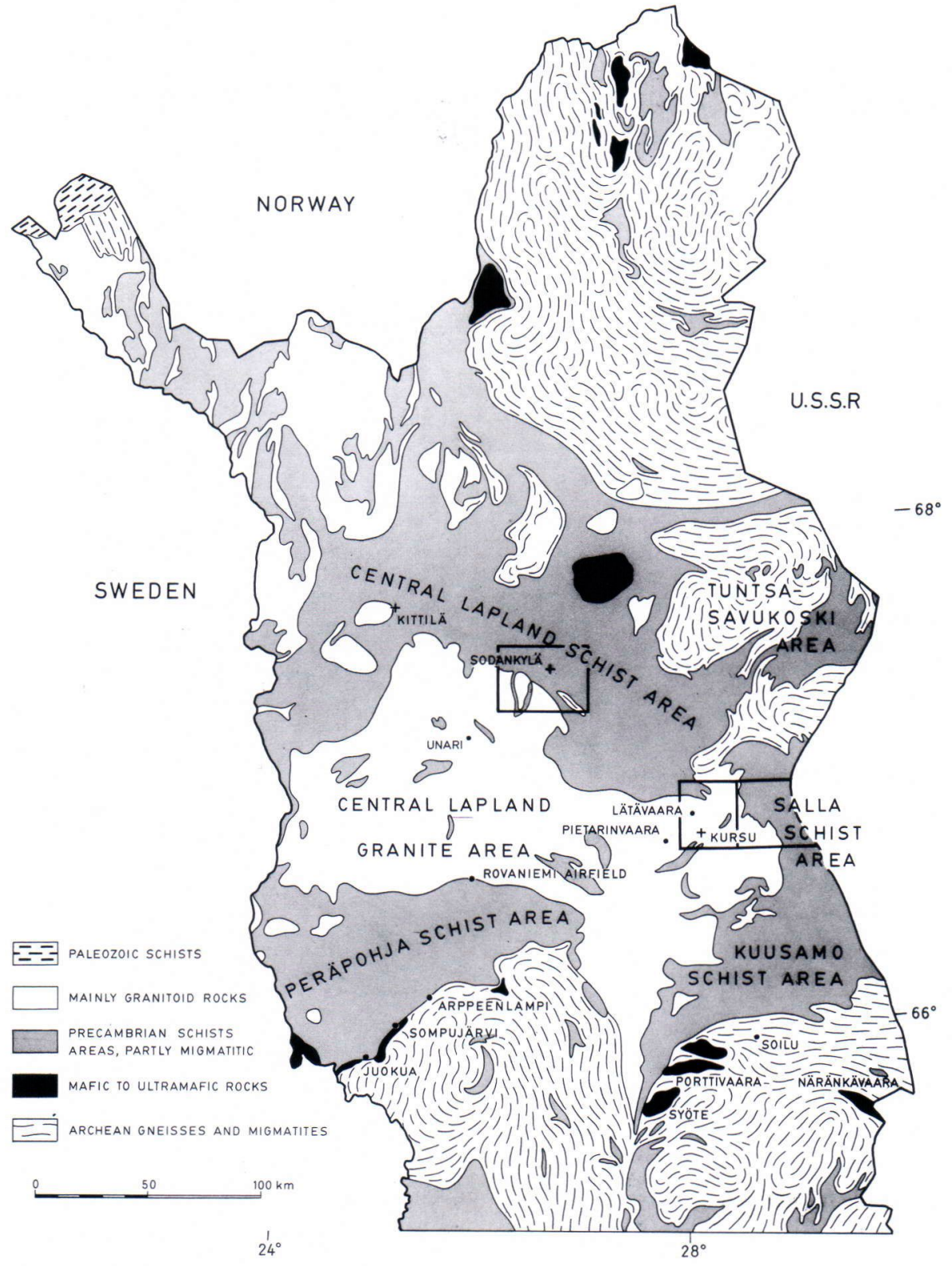

Fig. 1. Areas and localities referred to in the text. The areas of map sheets $3643 \mathrm{Kursu}, 4621$ Salla and 3713 Sodankylä are marked with quadrangles. These base map is simplified from Simonen (1980 a). 
Owing to the limited man-power assigned to this task, usually one or two geologists and a few field assistants, the inferiority of the field maps and the difficulty of working in large nearly unpopulated areas, these maps leave much to be desired. Hackman (1927, p. 97) proposed new investigations in some areas covered by the maps that he himself had compiled and Mikkola (1941, p. 7) considered that all of the maps should be revised and reprinted.

The remapping of the Precambrian bedrock in northern Finland was started in the early $1960 \mathrm{~s}$, this time at a scale of $1: 100000$. So far this mapping is limited to parts of the schist areas of Peräpohja, Kuusamo, Salla and Central Lapland (Fig. 1) and their immediate environment. Consequently, knowledge of the geology of these areas has been much enhanced in the last two decades, but it has remained nearly unchanged, part of it since 1910 , in the central parts of areas composed mainly of granitoid rocks and migmatites.

Sederholm (1892) gave detailed instructions as to how the field observations for the general geological mapping were to be carried out. Most rocks, especially plutonic rocks and schists, were to be placed in one of two categories, older or younger. In addition to contact relations the main criterion for the age of rocks was the degree of metamorphism and granitization.

The consequences of this mapping method in northern Finland are still visible in Sheet 2 of the Carte Géologique Internationale de l'Europe (1966). On this map most of the "young-looking», i.e., massive, mostly reddish non-cataclastic granitoid rocks in the Archean basement complexes south of the schist areas of Peräpohja and Kuusamo and northeast of the schist area of Central Lapland (Fig. 1) are designated as late Karelian (i.e. Proterozoic) granites. On the basis of radiometric age determinations, mainly made by $\mathrm{U}-\mathrm{Pb}$ methods on zircons and titanites, however, most of these granites are nowdays regarded as Archean (e.g. Simonen 1971, $1980 \mathrm{a}, \mathrm{b})$.

\section{Age relations and mineral ages in the Kuusamo area}

Neither granitic veins intruding the schists nor basal conglomerates had been found on the southern border of the Kuusamo schist area (Fig. 1) before the remapping of the area and, therefore, the contact between the underlying gneissose basement and the schists was supposed to be tectonic (Väyrynen 1954, p. 191; Simonen 1964, p. 68). In the late 1960s several occurrences of basal conglomerates were found along the contact. They have been described by Silvennoinen (1972).

Samples for age determinations were taken from a reddish, homogeneous granite and two pegmatite dykes in the basement complex near Soilu, about $10 \mathrm{~km}$ south of the Kuusamo schist area (Fig. 1). Field observations indicate that these samples represent the youngest granitic rocks in this area.

The $\mathrm{U}-\mathrm{Pb}$ age determinations reported in the present paper were all made at the Geological Survey of Finland. The ages were calculated with the decay constants given by Jaffey et al. (1971). Some of the age data reported here have been published previously in Annual Reports of the Geological Survey of Finland (GSF, Ann. Rep.) using older constants (until 1972) and/or without calculated diffusion model ages.

Analytical data on zircons from the Soilu area are given in Table 1; a concordia diagram is given in Fig. 2. Their ages, $2738 \mathrm{Ma}$ and $2712 \mathrm{Ma}$, agree well with the ages obtained for the granitoid rocks surrounding and intruding the greenstone belts of Suomussalmi and Kuhmo (e.g. Kouvo \& Tilton 1966, Geological Survey of Finland, Petrological 


\begin{tabular}{|c|c|c|c|c|c|c|c|c|c|c|}
\hline \multirow{3}{*}{$\begin{array}{l}\text { Local- } \\
\text { ity/ } \\
\text { Sample } \\
\text { No. }\end{array}$} & \multirow{3}{*}{$\begin{array}{l}\text { Zircon fraction } \\
\mathrm{d}=\mathrm{g} / \mathrm{cm}^{3} \\
\mathrm{~m}=\text { grain size } \mu \mathrm{m}\end{array}$} & \multirow{3}{*}{$\begin{array}{l}{ }^{238} \mathrm{U} \\
\mathrm{ppm}\end{array}$} & \multirow{3}{*}{$\begin{array}{l}\text { Radiogenic } \\
{ }^{206} \mathrm{~Pb}, \mathrm{ppm}\end{array}$} & \multirow{3}{*}{$\begin{array}{c}{ }^{206} \mathrm{~Pb} \\
{ }^{204} \mathrm{~Pb} \\
\text { (measu- } \\
\text { red) }\end{array}$} & \multirow{2}{*}{\multicolumn{3}{|c|}{$\begin{array}{l}\text { Isotopic abundance } \\
\text { relative to }{ }^{206} \mathrm{~Pb}(=100)\end{array}$}} & \multicolumn{3}{|c|}{ Radiometric ages, Ma } \\
\hline & & & & & & & & \multirow{2}{*}{${ }^{206} \mathrm{~Pb}$} & \multirow{2}{*}{$\frac{{ }^{207} \mathrm{~Pb}}{{ }^{235} \mathrm{U}}$} & \multirow{2}{*}{$\frac{{ }^{207} \mathrm{~Pb}}{{ }^{206} \mathrm{~Pb}}$} \\
\hline & & & & & 204 & 207 & 208 & & & \\
\hline \multicolumn{11}{|l|}{ Soilu: } \\
\hline A415A & $\mathrm{d}>4.0 ; \mathrm{m}>130$ & 507.7 & 203.44 & 2852 & .03284 & 19.055 & 10.998 & $2453 \pm 12$ & $2597 \pm 6$ & $2712 \pm 4$ \\
\hline $\mathrm{A} 424 \mathrm{~A}$ & total & 1004.2 & 261.76 & 655.9 & .12718 & 18.976 & 19.632 & $1697 \pm 12$ & $2139 \pm 10$ & $2595 \pm 13$ \\
\hline A $425 \mathrm{~A}$ & $\mathrm{~d}>4.2 ; \mathrm{m}>160$ & 525.1 & 216.04 & 3236 & .02825 & 18.743 & 12.491 & $2507 \pm 13$ & $2609 \pm 6$ & $2689 \pm 3$ \\
\hline A425B & $\begin{array}{l}4.0<\mathrm{d}<4.2 \\
\mathrm{~m}>160\end{array}$ & 895.1 & 350.33 & 2159 & .04529 & 18.921 & 12.264 & $2405 \pm 12$ & $2560 \pm 6$ & $2685 \pm 3$ \\
\hline
\end{tabular}

Hatajavaara:

\begin{tabular}{|c|c|c|c|c|c|c|c|c|c|c|}
\hline $\begin{array}{r}\mathrm{A} 126 \mathrm{~A} \\
\mathrm{~B} \\
\mathrm{C}\end{array}$ & $\begin{array}{l}\mathrm{d}>3.8 ; m>70 \\
\mathrm{~d}>3.8 ; 50<\mathrm{m}<70 \\
\mathrm{~d}>3.8 ; \mathrm{m}<50\end{array}$ & $\begin{array}{l}609.7 \\
664.1 \\
705.6\end{array}$ & $\begin{array}{l}162.12 \\
170.57 \\
176.30\end{array}$ & $\begin{array}{l}1518 \\
1213 \\
1040\end{array}$ & $\begin{array}{l}.06354 \\
.08058 \\
.09366\end{array}$ & $\begin{array}{l}12.968 \\
12.746 \\
12.567\end{array}$ & $\begin{array}{l}13.305 \\
17.553 \\
22.154\end{array}$ & $\begin{array}{l}1727 \pm 9 \\
1675 \pm 9 \\
1635 \pm 9\end{array}$ & $\begin{array}{l}1841 \pm 5 \\
1780 \pm 6 \\
1730 \pm 6\end{array}$ & $\begin{array}{l}1974 \pm 6 \\
1905 \pm 7 \\
1848 \pm 7\end{array}$ \\
\hline $\begin{array}{r}\mathrm{A} 640 \mathrm{~A} \\
\mathrm{~B}\end{array}$ & $\begin{array}{l}d>4.6 \\
4.2<d<4.6 \\
m>70\end{array}$ & $\begin{array}{l}417.1 \\
577.6\end{array}$ & $\begin{array}{l}113.12 \\
156.16\end{array}$ & $\begin{array}{l}2577 \\
1905\end{array}$ & $\begin{array}{l}.03687 \\
.05119\end{array}$ & $\begin{array}{l}12.738 \\
13.001\end{array}$ & $\begin{array}{r}222.623 \\
18.393\end{array}$ & $\begin{array}{l}1757 \pm 10 \\
1752 \pm 9\end{array}$ & $\begin{array}{l}1867 \pm 6 \\
1870 \pm 6\end{array}$ & $\begin{array}{l}1992 \pm 5 \\
2003 \pm 4\end{array}$ \\
\hline C & $\begin{array}{l}4.0<d<4.2 \\
m>70\end{array}$ & 914.3 & 240.20 & 1374 & .07217 & 13.087 & 14.786 & $1709 \pm 9$ & $1832 \pm 6$ & $1974 \pm 8$ \\
\hline A641A & $\begin{array}{l}4.2<d<4.6 \\
m<70\end{array}$ & 493.6 & 132.58 & 3835 & .02528 & 12.354 & 19.115 & $1742 \pm 12$ & $1843 \pm 7$ & $1958 \pm 3$ \\
\hline B & $\begin{array}{l}4.2<\mathrm{d}<4.6 \\
\mathrm{~m}>160\end{array}$ & 423.8 & 117.86 & 3947 & .02295 & 12.856 & 11.959 & $1796 \pm 10$ & $1910 \pm 6$ & $2036 \pm 4$ \\
\hline $\mathrm{C}$ & $\begin{array}{l}4.2<\mathrm{d}<4.6 \\
70<\mathrm{m}<160\end{array}$ & 474.2 & 130.68 & 4650 & .02085 & 12.802 & 13.749 & $1782 \pm 12$ & $1900 \pm 7$ & $2032 \pm 3$ \\
\hline $\mathrm{D}$ & $\begin{array}{l}4.0<d<4.2 \\
m>70\end{array}$ & 876.6 & 225.67 & 2481 & .03898 & 12.581 & 12.602 & $1679 \pm 9$ & $1810 \pm 6$ & $1965 \pm 4$ \\
\hline $\mathrm{E}$ & $\begin{array}{l}4.0<\mathrm{d}<4.2 \\
\mathrm{~m}<70 ; \mathrm{HF}\end{array}$ & 325.2 & 77.68 & 11101 & .005782 & 11.671 & 25.463 & $1571 \pm 9$ & $1714 \pm 6$ & $1894 \pm 4$ \\
\hline $\mathrm{F}$ & $\begin{array}{l}4.0<\mathrm{d}<4.2 \\
\text { light coloured } \\
\text { long crystals } \\
\mathrm{m}>70\end{array}$ & 765.1 & 178.74 & 1360 & .05961 & 11.683 & 20.660 & $1540 \pm 10$ & $1643 \pm 7$ & $1778 \pm 12$ \\
\hline G & $\begin{array}{l}4.0<\mathrm{d}<4.2 \\
\mathrm{~m}>70\end{array}$ & 852.0 & 222.76 & 3151 & .03080 & 12.726 & 11.135 & $1702 \pm 9$ & $1840 \pm 5$ & $2002 \pm 3$ \\
\hline
\end{tabular}




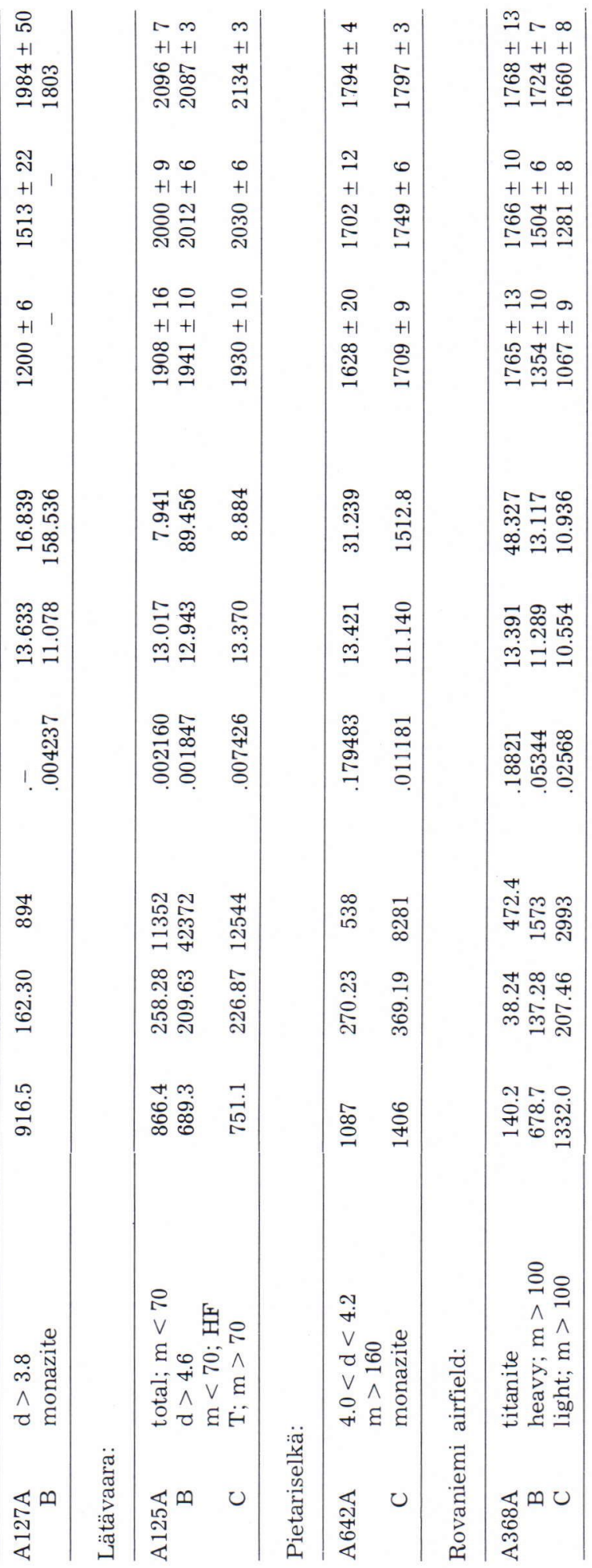

Department. Reports on activities in years 1980 and 1981, Hyppönen 1982).

\section{Age relations of rocks in the Peräpohja area}

Some granites south of the Peräpohja schist area were designated by Hackman (1910b, 1918) as post-Kalevian, i.e., younger than most of the schists. Härme (1949, pp. 36-37) assumed that the granite near Juokua (Fig. 1) is younger than the quartzite overlying it because microcline-quartz veins were found in the quartzite. Simonen (1964, p. 72) supposed that the contact between the schists and the underlying granite gneiss basement was tectonic because basal conglomerates had not been found.

Remapping of the area and radiometric age determinations have altered some earlier concepts. Several occurrences of basal conglomerates have been found. In some places pink homogeneous granite in the underlying basement grades over a few tens of metres into basal conglomerate containing pebbles of the same granite. A convincing example of this is seen near Arppeenlampi (Perttunen 1971, 1980 and pers. comm.) In places like this the granite is definitely older than the schists. What is more, $\mathrm{U}-\mathrm{Pb}$ data on zircons from the granite underlying the basic rocks near Sompujärvi (Kouvo \& Tilton 1966) and from a granitic pebble in the Sompujärvi conglomerate (GSF, Ann. Rep. 1974) show Archean ages. The Sompujärvi conglomerate has been described by Härme (1949). The location of Arppeenlampi and Sompujärvi is shown in Fig. 1.

In the light of investigations published so far it seems obvious that even the "youngestlooking» granitic rocks southeast of the schist belts of Peräpohja and Kuusamo are of Archean age. The phenomena indicating partial refusion of the basement granitoid rocks (e.g. Härme 1949; Kouvo \& Tilton 1966, pp. 438-439; Kujanpää 1971) may be attrib- 


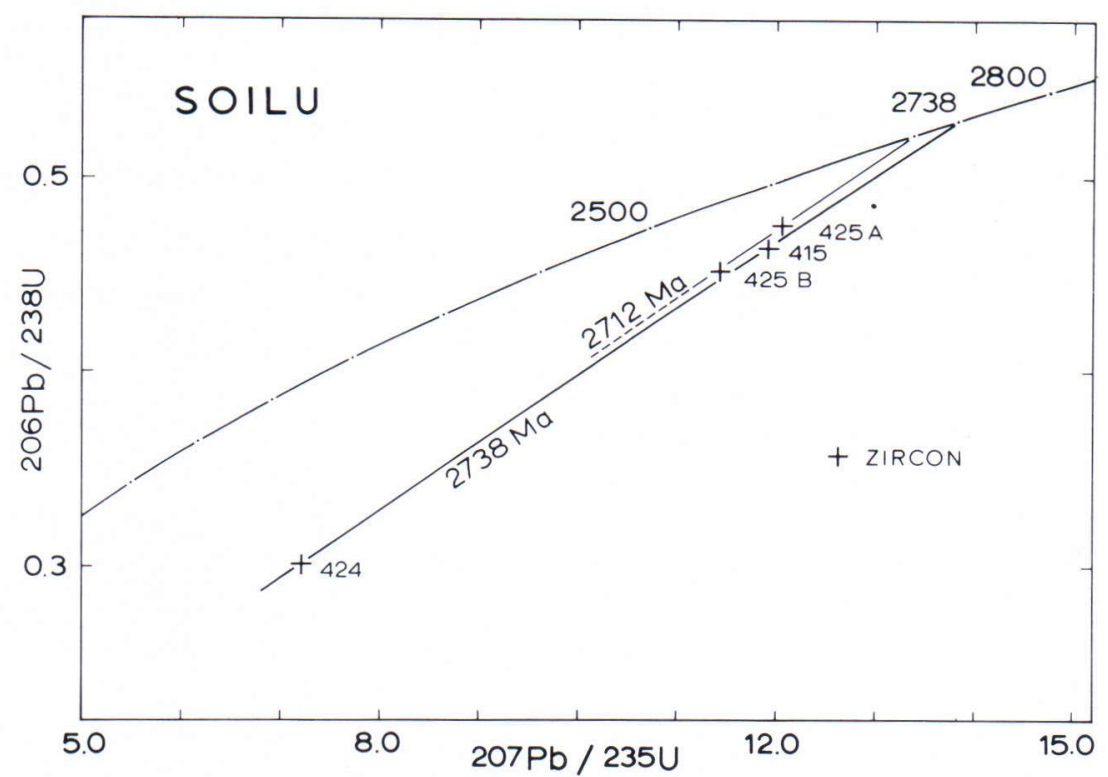

Fig. 2. $\mathrm{U}-\mathrm{Pb}$ concordia plot for zircons from the Archean basement complex near Soilu, Kuusamo. Map sheet 4522 04. Sample A415 is from a reddish, homogeneous granite by road No. $4641(\mathrm{x}=7315.300, \mathrm{y}=$ 436.500); sample A424 is from a red pegmatite dyke a few tens of centimetres wide penetrating the same granite, and sample A425 is from a light grey pegmatite dyke penetrating migmatitic rock about $100 \mathrm{~m}$ south of the Soilu canal $(x=7316.300, y=438.400)$. Samples A415 and A424 fit the diffusion curve corresponding to an age of $2738 \mathrm{Ma}$. Analogously, the isotope ratios of two zircon fractions from sample A425 were deciphered through a $2712 \mathrm{Ma}$ diffusion model (Wasserburg 1963). The diffusion model ages are $2706 \mathrm{Ma}$ for the fraction $\mathrm{A} 425 \mathrm{~A}$ and $2717 \mathrm{Ma}$ for the fraction A425B.

uted to the effect of the heat of the mafic intrusions on their environment (Reino 1973).

\section{Mineral ages from the Salla area}

A part of the Salla schist area and of the granitoid and migmatite complex westward of it was mapped in 1961-67 (Lauerma 1967 a, b). The location of these map-sheet areas, 4621 Salla and 3643 Kursu, is shown in Fig. 1. The main geological features are shown in Fig. 3.

No basal conglomerates have been found in the area of these map sheets or elsewhere in the proximity of the western border of the Salla schist area. In many places granites intrude the supracrustal rocks, and schist inclusions have been found in the granitic rocks. These observations suggest that the granites are younger than the supracrustal rocks in their vicinity.

Numerous attempts have been made to date the rocks intruding the schists. Some of the rocks did not yield enough zircon, titanite or monazite to be reliably dated with $\mathrm{U}-\mathrm{Pb}$ methods. Interpretation of a great deal of the data obtained so far is ambiguous. Even so, the results do give some idea of the geological and geochronological problems encountered in this area. The localities from which the samples reported here were taken are shown in Fig. 3. Analytical data are given in Table 1 and some of the isotope ratios are plotted on the concordia diagram in Fig. 4.

Large outcrops of a rather homogeneous granite occur in Hatajavaara (Fig. 3). About $800 \mathrm{~m}$ north of it, in Paikanselkä, dykes of obviously the same granite intrude metadia- 


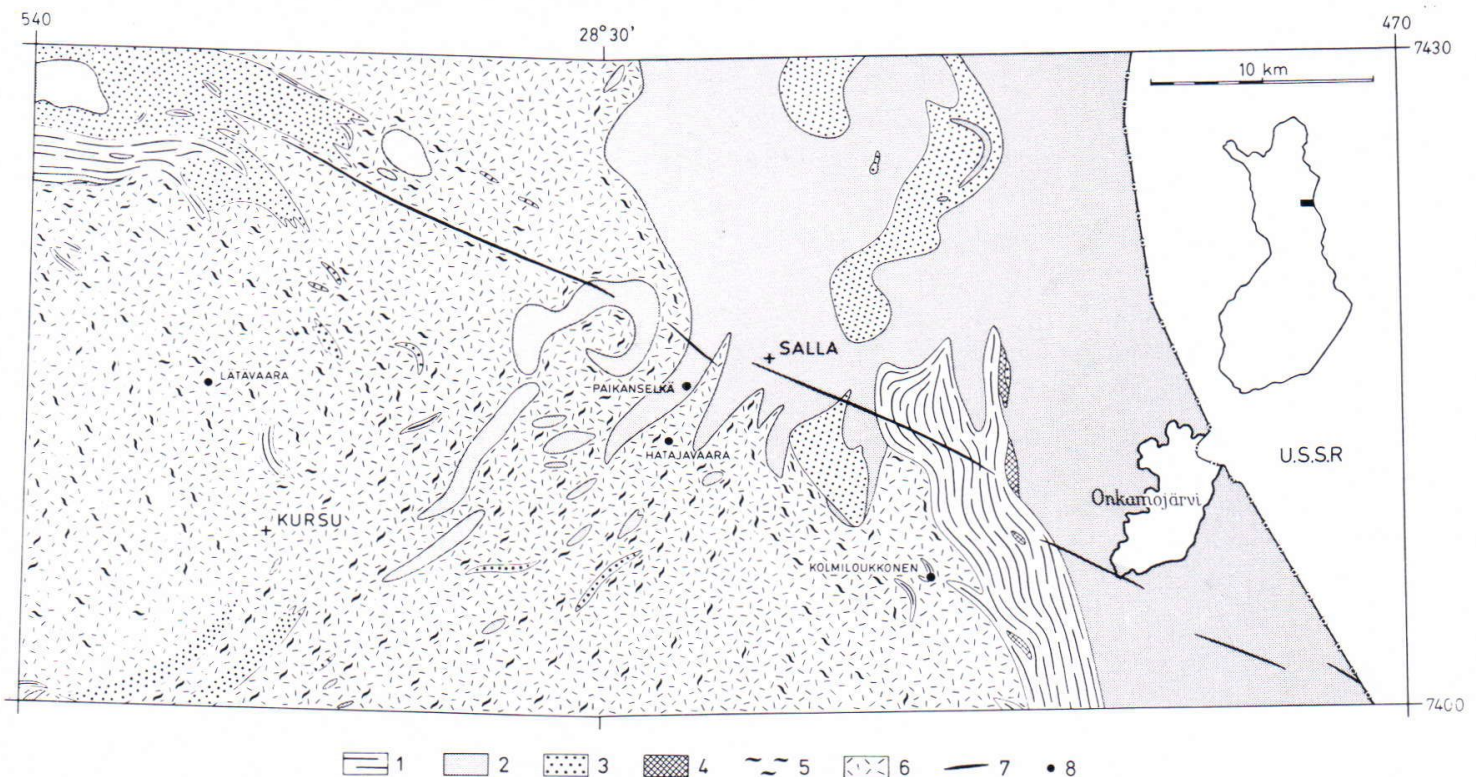

Fig. 3. Sources of the samples for age determinations from the Salla area. The base map is simplified from Lauerma (1967 a, b). 1. Mica schist and mica gneiss. 2. Metadiabase, amphibolite and hornblende gneiss. 3. Quartzite. 4. Dolomite and skarn. 5. Schist inclusions and schlieren. 6. Granite and granodiorite. 7. Diabase dyke. 8. Sample locality.

base (Lauerma 1967a). The width of the largest granite dyke found is difficult to estimate because the outcrop has been broken by frost action; it seems, however, to be about $20 \mathrm{~m}$ to $30 \mathrm{~m}$. Some other dykes are $1-2 \mathrm{~m}$ wide, and in a railway cut about $1 \mathrm{~km}$ farther northeast the granite dykes are only a few $\mathrm{cm}$ to some tens of $\mathrm{cm}$ wide. Three granite samples, Nos. A126, A640 and A641, were taken from a quarry near the northern margin of Hatajavaara. All of them proved to be exceptionally poor in zircon.

Sample A126 is from the most homogeneous granite, which contains some miarolitic cavities about $5 \mathrm{~cm}$ to $10 \mathrm{~cm}$ in diameter filled mainly with potassium feldspar but which exhibit neither schlieren nor veins. Three size fractions from the same density fraction $\left(\mathrm{d}>3.8 \mathrm{~g} / \mathrm{cm}^{3}\right)$ were analyzed. The finer fractions trend to be more discordant and slightly richer in uranium. The three size fractions are collinear. Fraction $+70 \mu \mathrm{m}$ is not far from the chord for sample A641, and the finest fraction corresponds to a diffusion curve of $1872 \mathrm{Ma}$. This could be interpreted by mixed population. Should the fractions be cogenetic, extension of the trajectory gives an upper intercept of $2531 \pm 14 \mathrm{Ma}$ and a fairly high lower intercept of $1422 \pm 5 \mathrm{Ma}$ on the concordia curve.

Sample A640 is from a pink granite with greyish schlieren, probably relics of mica gneiss inclusions. Three density fractions were analyzed. In all of them, the grain size is larger than $70 \mu \mathrm{m}$. Isotopic ratios are not far from the data points for sample A641. If a three-point isochrone (actually two points only, because fractions $\mathrm{A}$ and $\mathrm{B}$ gave nearly identical isotope ratios) were calculated, the upper intersection would be $2148 \mathrm{Ma}$ and the lower one $935 \mathrm{Ma}$.

Sample A641 is from a grey granite that contains some pegmatitic streaks and mica gneiss inclusions with sharp boundaries. 


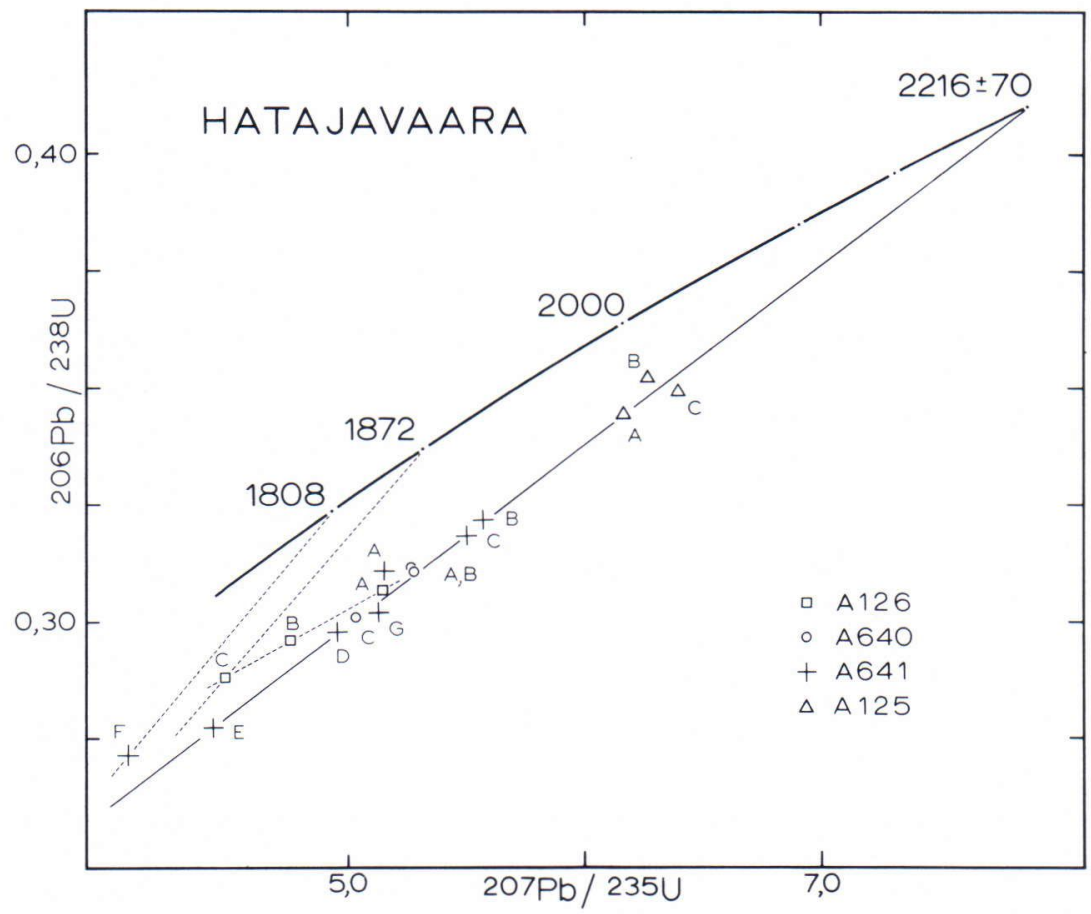

Fig. 4. Concordia diagram for zircons from the Hatajavaara granite (samples A126, A640 and A641) and from the Lätävaara migmatite (A125), Salla. The discordia array through data points B, C, G, D and E from the sample A641 (York 1966) gives an upper concordia intercept at $2216 \pm 70 \mathrm{Ma}$ (2 sigma error). When pooled, A640 and A641 yield an age of $2197 \pm 64 \mathrm{Ma}$. For reference, the dashed lines corresponding to the diffusion model ages of $1872 \mathrm{Ma}$ and $1808 \mathrm{Ma}$ were calculated through data points A126C and A641F (see text). The three zircon fractions from the Lätävaara migmatite sample (A125) are broadly consistent with the $2216 \mathrm{Ma}$ discordia age.

$\mathrm{MoS}_{2}$ was noted in the density fraction $+4.6 \mathrm{~g} / \mathrm{cm}^{3}$. The best fit chord based on four normal zircon fractions (B, C, G, D) and one zircon fraction preleached in hydrofluoric acid (fraction E) gives $2216 \pm 71 \mathrm{Ma}$ and a lower intercept of $1030 \pm 120 \mathrm{Ma}$. There is a general correlation between the degree of discordance and the uranium content (423$875 \mathrm{ppm} \mathrm{U})$ from the fraction $B$ to fraction D. An attempt to remove the discordant component with $\mathrm{HF}$ treatment was only partly succesful. Much common lead was removed, but the residue (fraction $\mathrm{E}$ ) had an uranium content of only $325 \mathrm{ppm}$ and was the most discordant of all fractions.

Fractions $\mathrm{A}$ and $\mathrm{F}$ of sample A641 were excluded when fitting the chord; the age given was $2216 \pm 70 \mathrm{Ma}$. Fraction $\mathrm{A}$, which has a density of $4.2-4.6 \mathrm{~g} / \mathrm{cm}^{3}$ and a grain size of less than $70 \mu \mathrm{m}$, gives a diffusion model age of $1983 \mathrm{Ma}$. Fraction F consists of light coloured long crystals, hand picked from a population with a density of $4.0-4.2 \mathrm{~g} / \mathrm{cm}^{3}$ and a grain size of $+70 \mu \mathrm{m}$. It is fairly rich in uranium and belongs to a diffusion chord of $1808 \mathrm{Ma}$. If all of the fractions from samples A640 and A641, excluding fractions A641A and $\mathrm{A} 641 \mathrm{~F}$, are pooled, they yield an age of $2197 \pm 64 \mathrm{Ma}$.

Irrespective of the collinearity of most of the zircon fractions from sample A641, the coexistence of definitely younger zircons made it difficult to assess the apparent isochron relationship. Even so, it is certain 
that the majority of the zircon population represents a minimum age of about $2200 \mathrm{Ma}$.

Sample A127 is from a small quarry near road No. 950, about $1 \mathrm{~km}$ north of the lake Kolmiloukkonen (Fig. 3), at a site where several hornblende-bearing mica schist layers and granite sills intercalate. The mica schist layers and the granite sills are both about $5 \mathrm{~m}$ to $10 \mathrm{~m}$ thick. The granite also intrudes the mica schist discordantly as veins a few $\mathrm{cm}$ thick. The sample was taken from the middle of a granite sill.

The sample proved to be very poor in zircons. The only zircon fraction $(\mathrm{d}>3.8 \mathrm{~g} /$ $\mathrm{cm}^{3}$ ) analyzed so far is highly discordant and shows a diffusion model age of $2137 \mathrm{Ma}$. The ${ }^{207} \mathrm{~Pb} /{ }^{206} \mathrm{~Pb}$ age on monazite from the same sample is only 1803 Ma. The common lead content in this monazite is very low $\left({ }^{206} \mathrm{~Pb} /\right.$ ${ }^{204} \mathrm{~Pb}=23596$ ).

The granitoid rocks near the western border of the Salla schist area are mostly homogeneous and contain few or no inclusions or schlieren. About $10 \mathrm{~km}$ to $20 \mathrm{~km}$ farther westward in the western part of the map sheet Kursu (Lauerma 1967 b) the rocks consist mainly of migmatites. There is also a marked difference in the aeromagnetic pattern of these two rocks. The migmatites give rather strong aeromagnetic anomalies but the homogeneous granites only very weak or none at all.

The migmatitic rocks, especially those in the vicinity of Lätävaara (Fig. 3), resemble those in many areas of the Archean basement of eastern Finland. Sample A125 was taken for age determination from the restite of such migmatite near the southern end of Lätävaara (map sheet 3643 02, $\mathrm{x}=7415.100, \mathrm{y}=$ 548.00). Three zircon fractions were analyzed. The analytical data are given in Table 1, and the isotopic ratios are plotted in Fig. 4 on the same concordia diagram as those of the Hatajavaara zircons. Despite their higher uranium content, zircons from Lätävaara are more concordant than those from the Hatajavaara granite. The isotopic ratios of fraction A fit on the chord of best fit for zircon fractions from sample A641 -Hatajavaara; those of fractions $\mathrm{B}$ and $\mathrm{C}$ from Lätävaara are not far from the same chord.

Isotope geological studies on the granitic rocks in Salla present two main problems. One is to date the intrusions of granites into the supracrustal rocks of the Salla schist belt; the other is to establish the source or sources of the zircon population in these granites and, thus, the material from which the granites derived.

Most of the zircon data on the Hatajavaara and Kolmiloukkonen granites indicate an anomalous age of about $2200 \mathrm{Ma}$. This age is by about $300 \mathrm{Ma}$ older than the typical synorogenic Svecokarelian age of about $1880 \mathrm{Ma}$ and by $400 \mathrm{Ma}$ older than the lateorogenic events. Disturbances on the concordia array (Fig. 4) indicate, however, that this is not a simple cogenetic suite of magmatically crystallized zircons. It is also possible, that due to high discordance or mixed population, or both, the fitted isochrone gives a minimum age only.

The Paikanselkä metadiabase north of Hatajavaara (Fig. 3) was dated by U-Pb methods. The samples were taken from a railway cut about $4 \mathrm{~km}$ west of Salla railway station. When plotted on a concordia diagram, the isotope ratios of zircons and titanite cluster in a rather small area and do not form a clear isochrone; even so, the preliminary ages obtained remain within $2100 \pm 50 \mathrm{Ma}$ (M. Sakko, pers. comm.).

As described previously, dykes of the Hatajavaara granite intrude the Paikanselkä metadiabase. Therefore, the granite dykes cannot have intruded earlier than some 2100 Ma ago. The youngest zircons (1808 Ma) from Hatajavaara and the monazite (1803 Ma) from Kolmiloukkonen indicate that it probably occurred about $1800 \mathrm{Ma}$ ago. 


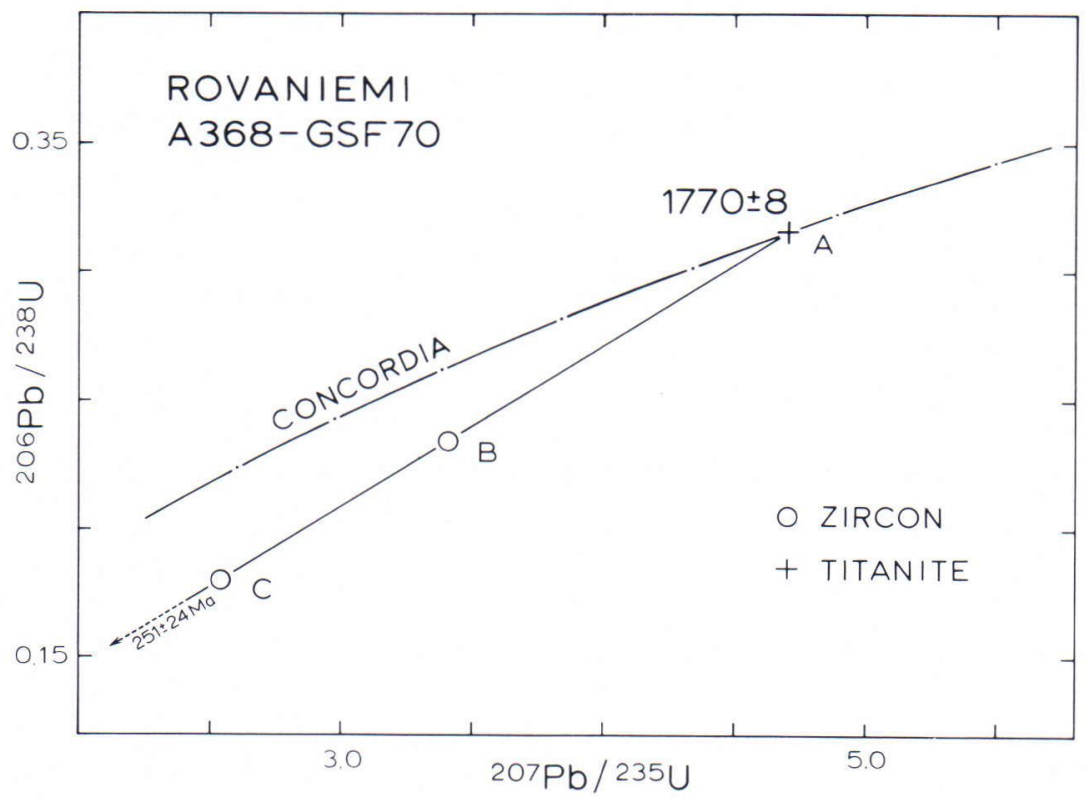

Fig. 5. Concordia diagram and $\mathrm{U}-\mathrm{Pb}$ isotope ratios for two zircons and one titanite from a granite, Rovaniemi airfield (map sheet $361208, \mathrm{x}=7386.800, \mathrm{y}=447.500$ ). Analytical data are given in Table 1 . The discordia array calculated according to York (1966).

The source of the zircon population in the granitic rocks in Salla is still unsolved. Other isotopic techniques (e.g., Sm-Nd, Lu-Hf and $\mathrm{Rb}-\mathrm{Sr}$ ) could further elucidate this problem and aid in establishing the material from which these granites derived.

\section{The age of the Central Lapland granitoid complex}

In addition to the rocks from Salla, two other granites have been dated from the eastern and southern part of the Central Lapland granitoid area (Fig. 1).

Sample A642 was taken from a grey homogeneous granite near Pietariselkä, about 20 $\mathrm{km}$ east of the town of Kemijärvi (map sheet $364110, \mathrm{x}=7401.050, \mathrm{y}=535.650$, northern side of a road cut on highway No. 5). The surrounding rocks are mainly various migmatites penetrated in places by pink granite. The only zircon fraction ( $\mathrm{d}=4.0-4.2 \mathrm{~g} / \mathrm{cm}^{3}$, grain size $>160 \mu \mathrm{m}$ ) analyzed gave a diffusion model age of 1819 Ma. Monazite from the same sample gave an age of $1805 \mathrm{Ma}$. Analytical data are given in Table 1.

North of the town of Rovaniemi granites and pegmatites intrude the quartzites of the Peräpohja schist area. A granite sample, A368, was taken by J. Nuutilainen (Rautaruukki Co.) from the northern margin of the Rovaniemi airfield. Analytical data on two zircon fractions and one titanite are given in Table 1. Isotopic ratios, which are plotted on a concordia diagram in Fig. 5 , give an age of $1770 \pm 8 \mathrm{Ma}$.

According to contact observations and most age determinations, the Central Lapland granitoid complex is late Svecokarelian in age. Within a larger framework, however, its geological setting suggests that it previously formed the basement for the Proterozoic sedimentation and was a source of some of the sedimentary material.

The complex is surrounded in most directions by Svecokarelian schist belts with 


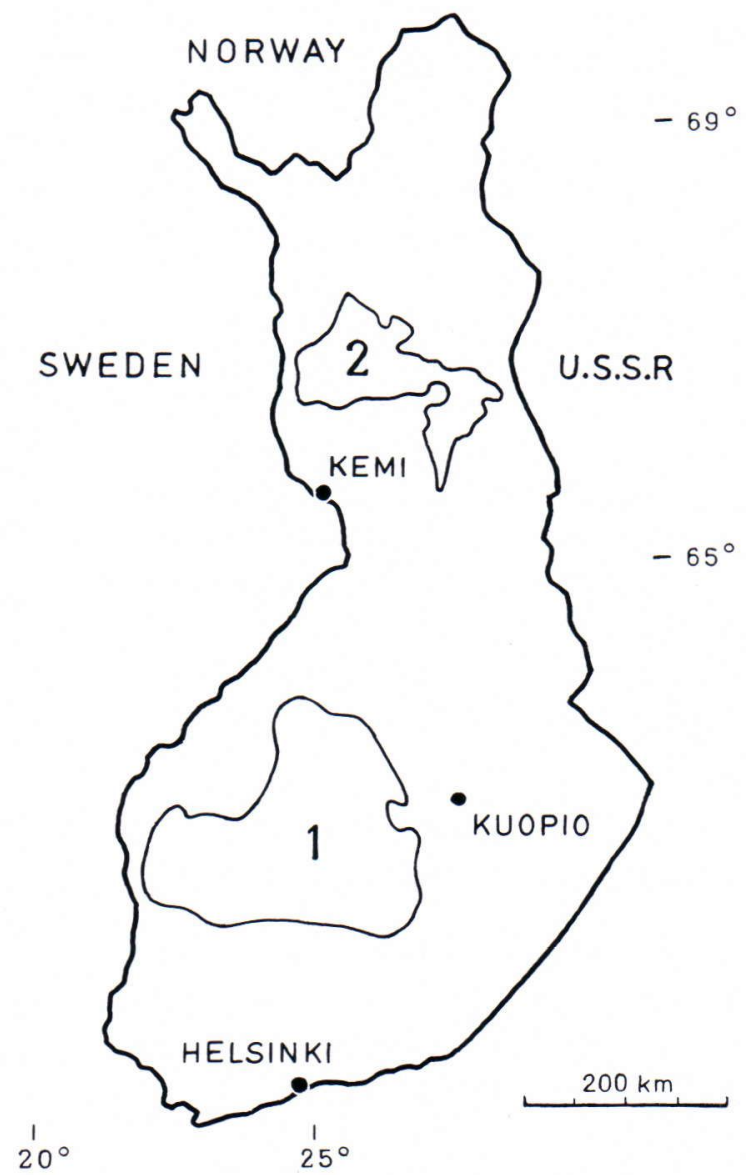

Fig. 6. Location of the granitoid areas of Central Finland (1) and Central Lapland (2).

quartzites in their marginal parts. The schist belts of Peräpohja, Kuusamo and Salla each form a synclinorium, underlain on one side by an Archean basement and intruded on the other by granitoid rocks (the eastern part of the Salla schist area is located in the territory of the U.S.S.R.) The supracrustal rocks apparently deposited on an Archean basement even in those regions where they are now penetrated by granitoid rocks. According to Hausen (1936), the rocks near the northern margin of the Peräpohja schist area have undergone regional anatexis.

Farther away from these schist areas, the penetrating, mostly massive granites often grade into migmatites similar to the Archean basement gneisses in eastern Finland. In some places, e.g., in the vicinity of Unari (Fig. 1) the migmatites display conspicuously gently dipping or subhorizontal foliation and banding.

According to Mikkola $(1937,1941)$ and Tyrväinen (1979) there occur probably Archean basement rocks south of Sodankylä (Fig. 1), in the northern part of the Central Lapland granitoid area.

The age problems of the Central Lapland granitoid and migmatite complex are partly the same as those of the mantled gneiss domes described by Eskola (1949). In these domes an old granitoid basement was covered by sediments and, together, they were upheaved and granitized during the following orogeny.

The age relations of the granitoid rocks and the overlying sedimentary cover can be solved in their contact zone, but in larger granitoid areas such as the Central Lapland granitoid complex farther away from the schist belts it is difficult to distinguish the possible Archean granitoid rocks from the Proterozoic ones by field investigations alone.

The isotope geological difficulties of dating various events in the development of mantled gneiss domes and in palingenic and polymetamorphic rocks in general has been elucidated by many examples from the Finnish Precambrian. Kouvo and Tilton (1966) have reported mineral ages from the mantled gneiss domes in Kuopio, Central Finland (Fig. 6). For the granitic cores of these domes the U-Pb data on zircons suggest an age of $2800 \mathrm{Ma}$, whereas biotites in the same rocks dated by $\mathrm{Rb}-\mathrm{Sr}$ and $\mathrm{K}-\mathrm{Ar}$ methods give ages from $1715 \mathrm{Ma}$ to $1800 \mathrm{Ma}$. Data on similar gneiss domes in the Kotalahti area, about $30 \mathrm{~km}$ south of Kuopio, published by Gaál (1980), indicate an age of about $2800 \mathrm{Ma}$ for the zircons, $1830 \mathrm{Ma}$ to $1850 \mathrm{Ma}$ for the 
titanites and an K-Ar age of about $1670 \mathrm{Ma}$ to $1730 \mathrm{Ma}$ for the biotites.

New data on the Sotkuma gneissose granodiorite dome, eastern Finland, give a zircon isochron showing the upper intersection of concordia at $2682 \mathrm{Ma}$ (O. Kouvo, pers. comm.) but monazite from the same sample gives an almost concordant age of $1900 \mathrm{Ma}$. (GSF, Petrological Dept. Ann. Rep. 1981).

Two zircon generations, long needles with an age of about $1900 \mathrm{Ma}$ and darker, roundish crystals with an age of about $2600 \mathrm{Ma}$, have been found in the same granodiorite (sample A32) from Kaavinkoski, eastern Finland (Huhma 1976). In northern Finland two zircon generations with ages of $3110 \pm 17 \mathrm{Ma}$ and $3069 \pm 16 \mathrm{Ma}$ in samples from the Tojottamanselkä tonalitic gneiss have been reported by Kröner et al. (1981). Titanite with an age of $2776 \mathrm{Ma}$ and a monazite dated at $1902 \mathrm{Ma}$ have been found within samples from the same locality (GSF, Petrological Dept. Ann. Rep. 1980; O. Kouvo, pers. comm.)

The examples given in the foregoing show that concepts like » the age of a rock» and » the age of a granitoid complex» are ambiguous, especially when applied to palingenic and polymetamorphic rocks and based on one dated mineral only.

The first attempts to find isotopic evidence of Archean rocks or minerals in the Central Lapland granitoid area were made in 1960s on migmatites in Lätävaara, Salla. The interpretation of the age and source of the zircon population in these rocks and in the granites of Hatajavaara and Kolmiloukkonen, described in the foregoing, is, however, not unambiguous.

The notion that some parts of the Central Lapland granitoid area are Archean in age has gained currency in the last 10 to 15 years and is now accepted by many geologists. According to Silvennoinen et al. (1980, p. 158), this granite is composed mainly of the melting products of the Archean basement complex formed during the main folding stage of the Svecokarelian orogeny. On their schematic stratigraphic map (op.cit.), they have marked as Archean most of the areas designated by Hackman (1910 a, b) and Hackman \& Wilkman (1925) as migmatitic mica gneisses.

The greatest part of the Central Lapland granitoid area was mapped in a rather cursory fashion about 45 to 85 years ago (Hackman 1910 a, b; Hackman and Wilkman 1925; Mikkola 1937). Aeromagnetic maps, surveyed in the $1960 \mathrm{~s}$, reveal new structural features in many parts of the area. Geological remapping of large areas and further isotopic studies are needed before the possible Archean and palingenic and anatectic parts of this granitoid and migmatite complex can be delineated.

\section{Chronostratigraphic implications}

On similar grounds as in the foregoing, viz., a large complex of granitoid rocks and migmatites surrounded by Proterozoic schist belts, areas of former Archean basement can be proposed in other parts of Finland as well. On the geological maps covering the whole of Finland (e.g. Simonen 1980 a) the most conspicuous of areas like this is the granitoid complex of Central Finland (Fig. 6). Its boundaries are, however, vague and difficult to delineate accurately on existing geological maps and even more so in the field.

Salop (1971) has proposed that this complex is possibly composed of older, mainly Archean palingenic granites. The radiometric age determinations made so far, however, including those on zircons, have all given Proterozoic ages (GSF Ann. Rep. 1966-78).

A recent trend in Finland has been to designate many of the schist areas or parts of them previously believed to be Proterozoic as Archean. One of these is the Salla schist area, which Gaál et al. (1978) have designated as an Archean (>2500 Ma) greenstone belt. Their 
opinion was partly based (op.cit., p. 206) on the $\mathrm{U}-\mathrm{Pb}$ age of zircons from the Hatajavaara granite, or, more properly, on the isotope ratios of the zircons from sample A126, reported in the GSF, Ann. Rep. 1973. As pointed out in the foregoing chapter, this granite, like the granite of Kolmiloukkonen, obviously intruded supracrustal rocks about $1800 \mathrm{Ma}$ ago; they do not, therefore, indicate an Archean age for the Salla schist area.

On their stratigraphic map, Silvennoinen et al. (1980) have marked the quartzites in the Salla schist area as Proterozoic and all the other supracrustal rocks as Archean ( $>2600$ $\mathrm{Ma}$ ). This view is apparently based on correlation with the chronostratigraphic model worked out by Silvennoinen (op.cit., Fig. 4) in the Kuusamo schist area. In this model the lowest members of the supracrustal column are of Archean age. Zircons separated from an acid volcanic rock in the western part of the schist area have given an age of $2790 \mathrm{Ma}$ (op.cit. p. 159) and this age has been used to date the extrusion of the lowermost, mainly mafic volcanic rocks of the sequence.

This model is not consistent with some of the data available at present. The age determinations of the granitoid rocks and pegmatites in the basement complex south of the Kuusamo schist area have given ages within 2600-2800 Ma (Kouvo \& Tilton 1966; GSF Ann. Rep. 1971-77; GSF Petrological Dept. Ann. Rep. 1980, 1981; Vidal et al. 1980; Hyppönen 1982; Fig. 2 in this paper). The schists overlie unconformably the basement complex, and in places basal conglomerates containing pebbles from the basement rocks are encountered. There are no reports of granitic veins intruding the schists in the southern border of the Kuusamo schist area. Therefore, also the lowermost volcanic rocks of the sequence are evidently younger than the granitic rocks in the underlying basement. The same volcanic rocks in the Soviet part of the Kuusamo schist belt belong, according to Kulikov et al. (1980), to the Sumian Sariolian group, which means that they cannot be much older than $2450 \mathrm{Ma}$ (Meriläinen \& Sokolov 1981, p. 13).

The crucial problem seems to be the pos1tion and age of the acid metavolcanic rock in the western part of the Kuusamo schist area, or, more properly, the primary source or sources of the zircon population in this rock. The same problem is also encountered elsewhere in northern Finland, where many supracrustal rocks have been proposed Archean (Gaál et al. 1978; Silvennoinen et al. 1980). The majority of the radiometric datings have been made by $\mathrm{U}-\mathrm{Pb}$ methods on zircons, titanites and monazites separated from various rocks. The ages obtained by these methods for mafic rocks in the schist areas of Kuusamo, Salla and Central Lapland do not exceed $2450 \mathrm{Ma}$. The Archean ages reported are all from granitoid rocks, quartzites and acid metavolcanic rocks (GSF, Ann. Rep. 1969-77; GSF, Petrological Dept. Ann. Rep. 1980). Kallio (1980, pp. 57-60) has listed seven previously published ages and reported four new ones from the Kittilä greenstone area. They range from $1834 \mathrm{Ma}$ to $2213 \mathrm{Ma}$. The Sm-Nd determinations, recently initiated at the Geological Survey of Finland, will probably give more age data, especially on mafic rocks within and overlying the Archean basement complexes in northern Finland.

The existence of Archean greenstone belts or other Archean mafic to ultramafic rocks in Finnish Lapland (north of the latitude $66^{\circ} \mathrm{N}$ ) is by no means excluded. It seems plausible that, as proposed by Gaál et al. (1978), some zones of mafic to ultramafic rocks in the Tuntsa-Savukoski area (Fig. 1) belong to this category. Their geological setting within an area composed of Archean granitoids and their aeromagnetic patterns are very similar to those of the Suomussalmi and Kuhmo greenstone belts. Yet, the northernmost greenstone belts in Finland, delineated so far 
by reasonably detailed geological mapping and dated as Archean by radiometric methods, are those of Suomussalmi and Kuhmo. The occurrences of mafic rocks in Syöte, Porttivaara and Näränkävaara, south of the Kuusamo schist area (Fig. 1), designated by Gaál et al. (op.cit. Fig. 1) as metavolcanics of Archean greenstone belt association, are mafic layered intrusions of the age group 2430-2450 Ma (Simonen 1980 a, b). The data reported by Alapieti (1982) have yielded an age of $2436 \pm 5$ Ma for these intrusions.

The bedrock in the Finnish part of the Salla schist area is poorly exposed and large areas of it are totally covered by glacial drift and peat bogs. Owing to the subarctic climate, most of the outcrops are broken by frost action; this renders reliable tectonic observations difficult or impossible in many places. In this respect, the Salla region is similar to the Central Lapland schist area. Aeromagnetic maps were available when the latest geological maps (Lauerma $1967 \mathrm{a}$, b) were compiled, but owing to the flight altitude $(150 \mathrm{~m})$ and the flight line separation $(400 \mathrm{~m})$, their resolution was not sufficient in structurally complicated areas. The investigations made to date (Hackman \& Wilkman 1925; Lauerma 1967 a, b) give only a broad outline of the geology in the Finnish part of the Salla schist area. The Soviet part of the schist area has obviously been investigated in much greater detail (Kulikov et al. 1980).

Analogies with other areas have been applied to the Salla schist area with conflicting results. Simonen (1980 a, b) has desig- nated it traditionally as Svecokarelian (i.e. Proterozoic), Silvennoinen et al. (1980) as partly Archean (>2600 Ma), partly Proterozoic, and Gaál et al. (1978) as an Archean (> $2500 \mathrm{Ma}$ ) greenstone belt. As mentioned by Kulikov et al. (1980), different interpretations have also been presented by Soviet researchers. The greatest discrepancy at present concerns the age of rocks on both sides of the border between Finland and the U.S.S.R., in the central part of the synclinorium. According to Silvennoinen et al. (op.cit.) the mafic metavolcanic rocks in the proximity of the border belong to the lowermost Archean members of the combined ArcheanProterozoic column and, according to Kulikov et al. (1980), to the uppermost Suisarian group of the Proterozoic sequence.

In some parts of the Salla schist area the only geological mapping carried out so far was at the beginning of this century. New investigations will undoubtedly alter the current concepts of the geology of this area. From the data available at present, however, the Salla schist area seems to be Proterozoic in age.

Acknowledgements. All the age determinations reported in this study were performed at the Geological Survey of Finland by Dr. Olavi Kouvo and his co-workers. Dr. Kouvo also read the manuscript and gave valuable advice and criticism. Mrs. Elsa Järvimäki draw the figures and Mrs. Gillian Häkli, B. A., corrected the English of the manuscript. I wish to express my sincere thanks to all of them.

\section{References}

Alapieti, T., 1982. The Koillismaa layered igneous complex, Finland - its structure, mineralogy and geochemistry, with emphasis on the distribution of chromium. Geol. Surv. Finland, Bull. 319. $116 \mathrm{p}$.

Carte géologique internationale de l'Europe, Feuille $D \cdot 2,2 e$ édition, 1966. Published by Bundesanstalt für Bodenforschung and Unesco, Hannover.

Gaál, G., Mikkola, A.\& Söderholm, B. 1978. Evolu- 
tion of the Archean crust in Finland. Precambrian Res. 6, 199-215.

Gaál, G., 1980. Geological setting and intrusion tectonics of the Kotalahti nickel-copper deposit, Finland. Bull. Geol. Soc. Finland 52, $101-$ 129.

Geological Survey of Finland. Annual reports on activities for the years 1965-78. Espoo.

Geological Survey of Finland. Petrological Department. Reports on activities for the years 1980, 1981. Espoo 1981, 1982 (in Finnish).

Eskola, P., 1949. The problem of mantled gneiss domes. Quart. J. Geol. Soc. London CIV., 461476.

Hackman, V., 1910 a. Vuorilajikartta, lehti B 6, Ylitornio. Suomen geologinen yleiskartta 1: 400000 .

Hackman, V., 1910 b. Vuorilajikartta, lehti C 6, Rovaniemi. Suomen geologinen yleiskartta $1: 400000$.

Hackman, V., 1918. Vuorilajikartan selitys. Lehdet C 6 Rovaniemi - B 5 Tornio - B 6 Ylitornio. Suomen geologinen yleiskartta 1: $400000.80 \mathrm{p}$.

Hackman, V., 1927. Studien über den Gesteinbau der Kittilä-Lappmark. Bull. Comm. Géol. Finlande 79. $105 \mathrm{p}$.

Hackman, V. \& Wilkman, W. W., 1925. Vuorilajikartta, lehti D 6, Kuolajärvi. Suomen geologinen yleiskartta 1: 400000 .

Härme, M., 1949. On the stratigraphical and structural geology of the Kemi area, northern Finland. Bull. Comm. Géol. Finlande 147. 60 p.

Hausen, H., 1936. The North-Bothnian downfold. Stratigraphical and tectonical studies in the sedimentary series between the lower course of the Torne river and the Kivalo ridge (Finland). Acta Acad. Aboensis. Math. et Phys. IX. 5. 86 p.

Huhma, A., 1976. New aspects to the geology of the Outokumpu region. Bull. Geol. Soc. Finland 48, $5-24$.

Hyppönen, V., 1982. Kallioperäkartan selitys, lehdet 4411 Ontojoki, 4412 Hiisijärvi ja 4413 Kuhmo. English summary: Explanation to the maps of Pre-Quaternary rocks. Sheets 4411 Ontojoki, 4412 Hiisijärvi and 4413 Kuhmo. Geological map of Finland $1: 100000$. (In print).

Jaffey, A.H., Flynn, K. F., Glendednin, L. E., Bentley, W. C. \& Essling, A. M., 1971. Precision measurement of half-lives and specific activities of ${ }^{235} \mathrm{U}$ and ${ }^{238} \mathrm{U}$. Phys. Rev. C 4, 1889-1906.

Kallio, M., 1980. Keski-Lapin liuskealue Itä-Kittilän ja Länsi-Sodankylän osalta. Osa II: Rakenne ja stratigrafia. Kuhmon ja Kittilän malmiprojektit. Oulun yliopisto. Raportti N:o 29. 67 p.
Kouvo, O. \& Tilton, G. R., 1966. Mineral ages from the Finnish Precambrian. J. Geol. 74, 421-442.

Kröner, A., Puustinen, K. \& Hickman, M., 1981. Geochronology of an Archean tonalitic gneiss dome in northern Finland and its relation with an unusual overlying volcanic conglomerate and komatiitic greenstone. Contrib. Mineral. Petrol. 76, 33-41.

Kujanpää, J., 1971. Malmiesiintymän geologia, 92-93. In: Outokumpu Oy:n Kemin kaivos ja Tornion tehtaat. Vuoriteollisuus 29. English summary.

Kulikov, V. S., Galdopina, L. P., Voinov, A. S., Golubev, A. I., Kashpirov, S. I., Polehovsky, Yu. S. \& Svetov, A. P., 1980. Jatulian geology of the Paanajärvi-Kuolajärvi synclinorium, 7396. In: Jatulian geology in the eastern part of the Baltic shield. Proceedings of a Finnish-Soviet Symposium held in Finland 21st-26th August 1979, ed. by A. Silvennoinen. The Committee for Scientific and Technical Co-operation between Finland and Soviet Union. Rovaniemi 1980. $251 \mathrm{p}$.

Lauerma, R., 1967 a. Pre-Quaternary rocks. Sheets $4621+4623$ Salla. Geological Map of Finland 1: 100000 .

Lauerma, R., 1967 b. Pre-Quaternary rocks. Sheet 3643 Kursu. Geological Map of Finland 1: 100000 .

Meriläinen, K. \& Sokolov, V. A., 1981. Some attainments and problems relating to the geology of the Jatulian formations in Finland and Soviet Karelia, 9-18. In: Geological, geochemical and geophysical investigations in the eastern part of the Baltic schield. Papers issued to the 10th General Meeting of the Finnish-Soviet Joint Geological Working Group, held in Rovaniemi, 7 th-11th September 1981, ed. by K. Puustinen. The Committee for Scientific and Technical Cooperation between Finland and the Soviet Union, Helsinki 1981. 229 p.

Mikkola, E., 1937. Pre-Quaternary rocks. Sheet C 7 Sodankylä. General Geological Map of Finland $1: 400000$.

Mikkola,E., 1941. Explanation to the map of rocks. Sheets B 7 - C 7 - D 7, Muonio-SodankyläTuntsa. General Geological Map of Finland $1: 400$ 000. $286 \mathrm{p}$.

Perttunen, V., 1971. Pre-Quaternary rocks. Sheet 2544 Runkaus. Geological Map of Finland $1: 100000$.

Perttunen, V., 1980. Stratigraphy of the Peräpohja area, 139-144. In: Jatulian geology in the eastern part of the Baltic shield. Proceedings of a 
Finnish-Soviet Symposium held in Finland 21st-26th August 1979, ed. by A. Silvennoinen. The Committee for Scientific and Technical Cooperation between Finland and Soviet Union. Rovaniemi 1980. $251 \mathrm{p}$.

Reino, J., 1973. Pohjois-Suomessa esiintyvien albitiittien petrografiasta ja geokemiasta. Unpubl. M.Sc. thesis. Univ. of Oulu. Dept. of Geology. $75 \mathrm{p}$.

Salop, L. I., 1971. Osnovnye cherty stratigrafii i tektoniki dokembriya Baltiyskogo shchita, 687. In: Problemy geologii dokembriya Baltiyskogo shchita i pokrova Ruskoy platformy. Trudy VSEGEI 175.

Sederholm, J. J., 1892. Promemoria för rekognosörer vid Finlands Geologiska Undersökning. Medd. från Industristyrelsen i Finland. 17, 6179.

Sederholm, J.J., 1903. Esipuhe, 1-4. In: Frosterus, B. Vuorilajikartan selitys. Lehti C 2 Mikkeli. Suomen geologinen kartta 1:400 000. Resumé en Français. 102 p.

Silvennoinen, A. 1972. On the stratigraphic and structural geology of the Rukatunturi area, northeastern Finland. Geol. Surv. Finland Bull. 257. $48 \mathrm{p}$.

Silvennoinen, A., Honkamo, M., Juopperi, H., Lehtonen, M., Mielikäinen, P., Perttunen, V., Rastas, P., Räsänen, J. \& Väänänen, J. 1980. Main features of the stratigraphy of North Finland, 153-162. In: Jatulian geology in the eastern part of the Baltic shield. Proceedings of a Finnish-Soviet Symposium held in Finland 21st26th August 1979, ed. by A. Silvennoinen. The Committee for Scientific and Technical Cooperation between Finland and Soviet Union. Rovaniemi. 1980. 251 p.

Simonen, A. Kallioperä, 49-124. In: Suomen geologia, ed. by K. Rankama. Kirjayhtymä, Helsinki. 414 p.

Simonen, A., 1971. Das Finnische Grundgebirge. Geol. Rdsch 60, 1406-1421.

Simonen, A., 1980 a. Prequaternary rocks of Finland $1: 1000$ 000. Geological Survey of Finland. Simonen, A., 1980 b. The Precambrian in Finland. Geol. Surv. Finland Bull. 304. 58 p.

Tyrväinen, A., 1979. Pre-Quaternary rocks. Sheet 3713 Sodankylä. Geological Map of Finland 1: 100000 .

Väyrynen, H., 1954. Suomen kallioperä, sen synty ja geologinen kehitys. Otava. Helsinki. 260 p.

Vidal, Ph., Blais, S., Jahn, B. M., Capdevila, R. \& Tilton, G. R., 1980. U-Pb and Rb-Sr systematics of the Suomussalmi Archean greenstone belt (Eastern Finland). Geochim. Cosmochim. Acta 44, 2033-2044.

Wasserburg, G. J., 1963. Diffusion processes in lead-uranium systems. J. Geophys. Res. 68, $4832-4846$.

York, S., 1966. Least-squares fitting on straight line. Can. J. Phys. 44, 1079-1086.

Manuscript received, May 7, 1982 